\title{
The Virgin Knight: Spenser's Embodiment of Duality in Elizabethan England
}

\author{
Chelsea Arsenault, English
}

\begin{abstract}
Edmund Spenser's poetry notoriously battles itself, contorting the surface of his poetical works into an ambiguous representation of how he perceived Elizabethan England in terms of theology, sexuality, nobility, and ideology. Written as what he termed "an historicall fiction[sic]," Spenser allowed his imagination to capture and epitomize the perspectives of Elizabethan society, but in a twisted fashion. The primary focus of appearance versus reality consumed him and became an encompassing factor of his work. In fact, he allowed one of his protagonists to become the embodiment of this struggle: Britomart, the virgin knight, who assumes a life of chastity and tribadism; ferocity and delicacy; the penetrator and the penetrated. Her conflicting roles as a chaste woman who exceeds the boundaries of expectation for her gender, encompasses her identity as an androgynous persona who refuses to abide by her expected gender performativity. When she confronts Malecasta at the House of loue, she becomes exposed to her conflicting, tense nature that fuels her essence as a penetrating virgin, allowing Spenser to indirectly expose Elizabethan England to restrictions on gender roles and sexuality due to his wordplays with language, means of representation, and repeated notions of dualism. Britomart, the virgin knight, embraces her character while serving as a canvas for Spenser to echo or defy common ideologies in Elizabethan England in terms of sexuality, chivalry, and identity.
\end{abstract}

The poetry of Edmund Spenser emerged in Elizabethan England from the struggle between two opposing elements of his nature: his drive for material ambition-dreams of wealth, importance, titles-which collided with his curiosity involving mystical idealism. These conflicting elements constantly surface in his poetical works, appearing in the form of a tense duality that is weaved with an opposition, taking the form of light versus dark, mysticism versus temporality, or appearance versus reality. In his work The Faerie Queene, he exaggerated this notion with metaphorical language to exemplify the tense duality. One character in particular however, who is introduced in Book III, becomes an encompassing image of conflicting attributes. Britomart, the female knight and protagonist, represents the inconsistency of appearance by remaining antithetical to her own reality. She pursues a man with vigor, but remains chaste; she disguises her femininity with armor, but is physically beautiful; and she 
identifies as both an aggressive knight, but nonetheless remains a delicate virgin. The tension revolving around Britomart's character summarizes the prime concept of The Faerie Queene, because the poem's duality becomes embedded within a persona. The virgin knight's duality becomes exposed during her stay at the Castle of Ioue, revealing the conflicting elements regarding her androgynous identity- her sexuality and gender-while serving as a direct, yet dualistic, challenge to Elizabethan England.

The English Renaissance hosted a plethora of new ideas and ideologies, revolving around literature, medicine, theology, law, astrology, and many other emerging factors that influenced society and its quotidian. Along with these new perspectives, the notion of the "hermaphrodite" surfaced in the face of literary and scientific works. However, this anatomical term correlated with sexual pursuits, becoming perceived as a "type of monster... correlative to same sex lovers, for it afforded the prospect of interchanging conventional gender roles in sex, and thus appeared to confound masculine and feminine functions, upset assumptions of clear gender distinction, and challenge restriction of coitus to encounters of opposite sexes" (Borris 228). The perception that commonly circulated during the English Renaissance, pertaining to the concept of performing outside of acceptable gender roles, became denoted as "monster-like," discouraging rebellion while emphasizing standard heteronormativity. In terms of Britomart's sexuality, she becomes perceived as a conundrum because she denies the sexual pursuit of another woman for the sake of preserving her womanhood as a chaste virgin, yet seizes the opportunity to express her sexuality in an aggressive, "masculine-associated" fashion that corresponds with her knighthood. Britomart's heroic womanhood reappears throughout the text, emphasizing her masculine traits while complimenting her feminine qualities.

When Britomart wakes to find Malecasta, her hostess for the night while resting at the Castle of Ioue, lying next to her in bed, her sexuality becomes compromised because she is presented with the temptation that could compromise her virtuous ways for a same-sex, erotic encounter. However, because she possesses masculine traits in a female body, her sexual encounter allows her to mimic a tribadic response - when a woman dominates and penetrates another womanwhich allows her to remain a woman while continuing to assert her male dominance in bed. In DiGangi's text "Fulfilling Venus," he notes that "what is at issue in condemnations of the tribas... is not homoerotic desire but gender transgression: the tribas was a "masculinized, phallic woman' (Halperin) or a 'butch' (Pellegrini) who violated the cultural norms of female passivity" (DiGangi 65). By defining a tribade as a woman who defies patriarchal norms with aggressive sexual acts, DiGangi proposes that a woman becomes a threat due to the fact that she refuses to be passive, and instead assumes a more penetrating (and dominating) role that is often reserved for a male in a patriarchal society. Therefore, to be a tribade, a woman must defy this traditional gender role in terms of sexual, penetrative acts and verbal or mental aggression, most often occurring in a female-female bond. Britomart encompasses these traits, and when she awakens to see Malecasta lying in bed next to her, she refuses to compromise her own virginity and reacts when she "lightly lept out of her filed bed,/ And to her weapon ran, in minde to gride/ The loathed leachour" (FQ III.i.63). Her immediate intuition involving the pursuit of a weapon instead of sexual action represents her intense aversion towards losing her virginity while "in 
minde to gride" Malecasta. The use of the word "gride," implying the desire to pierce and inflict pain, reflects how her sexual energy influences her immediate response to violently attack the "leachour" who has the intention of destroying her vow to chastity (OED Online). It also symbolically implies a tribadic response to the situation, allowing her to be the penetrator and not the penetrated. This aggressive stance adumbrates that she preserves her virginity and encourages her masculine side to overwhelm the sexual encounter, enforcing her desire to retain that dominating male perspective that she carries. Britomart's immediate response to Malecasta's pursuit insinuates that she guards her virginity when it is openly threatened, but she uses extreme and aggressive measures that parallel tribadism.

The notion of chivalry, which Britomart identifies due to her male exterior and battle-ready mentality, was perceived as a warrior code reserved for males since its emergence in the Middle Ages. Stemming from the French word "chevalrie," it literally meant "skill on horseback," but later evolved into a warrior code that stressed strength, conquest, and renown (McCoy 16). It becomes important to note that in the Elizabethan era, chivalry was "bound by social circumstances because they were composed for courtly performance" and were "devised to mediate conflicting interests within the ruling class" (McCoy 4). Spenser's consistent allusion to the conflict between appearance and reality becomes embedded in a figure of chivalry, but further perpetuates this notion by allowing a traditionally male-reserved space to be occupied by a female. Also, by personifying Britomart as a woman who exceeds the expectations in a role reserved for men to woo and revere women, he provokes the compromise of her sexuality. His detached perspective on the chivalric code is clearest when he twists it to exaggerate how all the traits that were solely correlated for a male become Britomart's strengths, as she respects and illuminates these virtues throughout her quest in The Faerie Queene. This notion allows her to be perceived as an invader to this male-reserved code while threatening the code of patriarchy.

Although Britomart conscientiously abjures and conceals the physicality of her female gender, traversing the boundaries of a feminine role, she does not assume the identity of a hermaphrodite or transgendered individual. She becomes physically perceived as a male, a knight who relies on her armor to signify her desired gender and the power that it conveys. At the Castle of Ioue, where she encounters the lustful Malecaste, Britomart refuses to disarm her armor contrary to the wishes of the Lady, "(For she her sexe vnder that straunge purport/ Did vse to hide, and plaine apparaunce shone:)" (FQ III.i.52). Britomart consciously continues to perpetuate the notion that she is a male knight by retaining her physical male disguise. Fisher notes that "a man's identity' had, prior to the Renaissance, been 'defined on the basis of patrilineal inheritance' and linked this ability to reproduce himself, but over time, an 'emergent culture' of 'performative masculinity' developed in which masculine identity was secured through the sexual 'conquest' of women" which was visibly broadcasted by armor-most notably the codpiece (69). The importance of the male façade, exaggerated by armor, exposes the power and prey distinction between the sexes. In terms of Britomart's identity as a male in the House of Ioue, she has the desire to propagate herself as a male through her armored exterior, which controls Malecasta's explicit sexual emotions that develop due to Britomart's assumed male physique and, therefore, role. Because Malecasta lustfully "told her briefe,/ That but if she did 
lend her short reliefe,/ And do her comfort, she mote algates dye," Britomart holds a sense of control over Malecasta due to the love she feels for Britomart, the knight (FQ III.i.530). The power Britomart gains from playing her male role acts as a means of dominance over the woman due to her knightly stature and Malecasta's irrefutable attachment to the knight. Ironically, the attention she attracts from Malecasta develops into a proposed sexual encounter that equalizes the power role, but while Britomart's exterior remains male, she retains the same power as a male. Her physical exterior conflicts with her inner virgin femininity, allowing the tension to build as Malecasta forcefully treats her in accordance with her male façade.

Since Britomart is frequently misinterpreted as a male, she is forced to confront the issues that occur with her anomalous identity that counteract her feminine virtues. For example, the misconception attracts problematic sexual encounters despite her chastity and consequently requires her to fight the alluring situations. When Malecasta pursues her, she wholeheartedly believes she's seducing a male knight since Britomart refuses to remove her armor and expose her female gender. As a result, Malecasta lies in bed with the intention of sleeping with the male knight Britomart, only to discover that she is "the warlike Mayd/ All in her snow-white smocke, with locks vnbownd,/ Threatning the point of her auenging blade" (FQ III.i.63). Britomart's character as "the warlike mayd" resonates as a female with the title as a "mayd," but one who antithetically possesses male tributes, since she is also perceived as "warlike." She perpetuates this male image with her swift and warrior-like actions, "threatning the point of her auenging blade," but the comedic perception of a pure and chaste woman in her "snow-white smocke" (which symbolizes her chaste position) exaggerates the amalgamate of her gender roles. The pure, physical beauty of a woman linked with the aggressive tension of a man encompasses Britomart's dual persona to embody her male and female attributes.

Britomart's identity in Spenser's work is not tethered to the challenge of representing a direct confrontation to the philosophies of patriarchy, however. She is also chosen as the exemplar of chastity to exemplify common standards during the Elizabethan era. In the Renaissance, women have been perceived as a complex gender that either paralleled the virtuousness of the Virgin Mary or represented the devil's gateway as an unchaste sexual predator. The feminine stereotype circulating throughout the years of the Renaissance perpetuated the ideology that a woman was valued for her beauty, denoting her physical attractiveness as her worth and putting her sexuality on a pedestal while emphasizing her frailty and value stemming from domesticity (Brown, MacBride). Therefore, chastity became one of the main attractive qualities that a woman could offer a man, and along with this virtue, the image of weakness. Spenser introduces Book Three of The Faerie Queene with an illustration of Chastity, enunciating its importance as "That fairest virtue, far above the rest" (FQ III.ii). Throughout the poetical work, Britomart's persona reflects a representation of Chastity, allowing her two main identities (penetrator and penetrated) to coalesce as one representative entity that fuels her sexuality.

Britomart's conflicting image sparks intensive debate pertaining to whether or not she is a delicate virgin, passively defending herself against penetration, or whether she is an aggressive knight who will pierce before she becomes pierced. Britomart's image as an assertive knight 
contrasts heavily with her persona as a virgin, exaggerating the binary between her gentle and her violent characteristics. As a virgin, she stereotypically fosters a tender and innocent image capable of trusting easily. She is preyed upon by Malecasta as "the bird, that knowes not the false fowlers call,/ Into his hidden net full easily doth fall" (FQ III.i.54). The simile denoting her character to a gentle bird, which commonly evokes the image of a beautiful and innocent creature, depicts Britomart as a weak virgin woman easily preyed upon by the malintent of Malecasta. Her threatened virginity in this instance becomes her identity, exaggerating her position as a delicate and chaste woman who is susceptible to succumbing to a dominating power's will. The propagation of this stereotype encompasses Britomart because she is unknowingly preyed upon by Malecasta. However, this weak version of Britomart, the version where she becomes the prey as opposed to the predator, contrasts heavily with her aggressive and unforgiving warrior image.

Spenser's devotion to Chastity also becomes a devotion to Britomart, and he represents her by saying that she serves as a mirror of this perfection. According to him, if an artist had to replicate her chastity, "his daedale hand would faile, and greatly faynt/... In picturing the parts of beauty daynt,/ so hard a workemanship adventure darre,/ For fear through want of words her excellence to marre." (FQ III.ii). He applauds her beauty and chastity to the extent that it becomes an accolade, but Spenser twists his language to introduce the tension that exists between her chastity and warrior-like presence. The resulting effects on the artist trying to replicate her beauty are not positive, and in fact appear to be violent and destructive. The artist faints and loses his notorious ability to craft anything from "his daedale hand," pronouncing the artist's prior infallibility concerning his skill, and her presence strikes fear into the illustrator to the extent that he shouldn't dare to try his hand at his "workemanship," because he would inevitably "marre" his work. However, the endorsed image of Chastity and its correlation with Britomart's embodiment allow her to be perceived as a beautiful and desirable woman. The fact that the language alludes to her warrior-like image as well however, instigates the tension in her character.

The divide between Spenser's praise to Chastity and his references to an image of aggression epitomizes Britomart's dual personality, which he enunciates through his language and use of wordplay. Anderson notes that "Spenserian wordplay" occurs often, and enunciates how "Spenserian etymology, at its most characteristic, does not look simply through the word to the thing but via the word to another story" (126). She describes how there is a sense in which it becomes necessary to look through the word, or dissect it for an alternative meaning to reveal Spenser's hidden message. His use of language allows it to resonate with a dualistic meaning, which he embeds in Britomart's existence when he describes her and her conflicting essence. For example, in the same introduction to Book III, Spenser advises virtuous women to regard their chastity in the same way that one would admire a portrait-but this is merely the surface interpretation. He says "to all ladies Which have it profest,/ Neede but behold the pourtraict of her hart" (FQ III.ii). He recommends that Britomart follows her chaste virtues by regarding her heart and admiring its attractiveness, which was a typical warning for a woman of the 
Renaissance; however, the spelling of the word "hart" in this quote indulges in an alternative meaning that results in an ambiguous perception of Britomart's identity.

Britomart's notorious conquering of males throughout The Faerie Queene allows this portrait of the "heart" to contort into a symbol of her success as a knight who dominates other males. The spelling of the word "hart" surfaces throughout the poem, but most dramatically affects Britomart's character when Spenser uses a particular spelling to contort her identity when referring to Malecasta's pursuit of Britomart in the House of Ioue. It challenges her virgin and knight binary. For example, Britomart becomes Malecasta's target, when "still did she rove at her with crafty glaunce/ Of her false eies, that at her hart did ayme" (FQ III.i.50). In terms of Britomart's position, her vow of chastity becomes presented in Spenser's ambiguous spelling and sentence structure that aligns with her duality. It can be said the Malecasta has her "heart" set on Britomart, but it can also allude to how Britomart becomes the hunted "hart," which is, according to the Oxford English Dictionary, a wild stag that can be hunted. Depending on the interpretation of the word, Britomart can be perceived as a creature capable of sentimental emotion, or a fierce animal that must protect herself by any means necessary. Throughout the encounter between Malecasta and Britomart, the female knight assumes two positions: the delicate virgin (who focuses on the "heart"), and the ferocious slayer (who focuses on the "hart").

While Britomart's masculine characteristics overshadow her feminine ones, her devotion to chastity enunciates her womanhood and is further exaggerated by Malecasta's antithetical representation of "Bad Chastity," which is the literal translation of her name. Spenser dedicates a passage of Book III to articulate the characteristics of womanhood. He echoes the ubiquitous belief that Womanhood is best denoted when "to loue captiued are,/ And chaste desires do nourish in your mind,/ Let not her fault your sweet affections marre,/ Ne blot the bounty of all womankind" (FQ III.i.49). By associating womanhood with the virtue of chastity, stressing the difference between love and "sweet affections," Britomart becomes perceived as a perfect example of womanhood because she not only refutes Malecasta's overt seduction, but she also refuses to engage in any sexual activity until she marries. However, it becomes further reinforced when regarding the ideology of the Renaissance in terms of a female's sexual drive, perpetuating chastity as a feat over "female-specified" biology.

Due to Malecasta's exemplification of the lustful woman, she represents the image of the typical Renaissance female who was perceived as a biologically more lustful and less perfect representation of the Renaissance male. The circulating studies pertaining to the study of female physiology revolved around the notion that a female's reproductive organs were simply the result of a failed development while in the womb, resulting in "an innate desire to achieve perfection by coupling with men"” (Mitchell, Osland 4). Britomart serves to perform the role of a woman who also identifies with male tendencies, while Malecasta submits to her "natural, biologically-engrained" lust by succumbing to her knight in shining armor. Her biologicallyengrained lust overcomes her and provokes her desire to lie with Britomart. This spectrum enunciates the dichotomy between Britomart's and Malecasta's different representations of the expected image of the Renaissance's ideology of womanhood because Britomart remains chaste and disproves any proposition concerning sexual energy. Malecasta "was giuen all to fleshly 
lust...So shamelesse beauty soone becomes a loathly sight” (FQ III.i.48) while Britomart is "'Mongst thousands good one wanton Dame to find:/ Emongst the Roses grow some wicked weeds" (FQ III.i.49). The binary relationship between Britomart and Malecasta emphasizes Britomart's image as the ideal woman, pronouncing her position as a female (according to Renaissance standards that wholly promote virginity as a symbol of desirable womanhood), while Malecasta serves to present the lustful antithesis who is undesirably frail in terms of protecting sexuality.

Although Britomart is associated with the identity of both a virgin and a knight, she allows the two to combine to fuel her character as a warrior that relies on her sexual energy to inspire her aggression. Her chastity provokes her success on the battlefield because she saves her sexual energy for Arthegall, the knight she pursues out of love, giving her incentive to battle. For example, when she flees the castle after the episode with Malecasta, Gardante shoots her with an arrow that "lightly rased her soft silken skin,/ That drops of purple bloud thereout did weepe,/ Which did her lilly smock staines of vermeil steepe" (FQ III.i.65). The allusion to a loss of virginity on the battlefield, assumed by the references to a white "lilly smock" (pure chastity) stained by "drops of purple bloud" (traditional bleeding alluding to the loss of a woman's virginity), evokes a correlation to Britomart's identity as a virgin knight who battles to retain her vow of chastity for Arthegall. The sexual correlation that revolves around Britomart's wound insinuates that the penetration from the fight relates to her virginal status and refers to her previous encounter with Malecasta who tried to steal her virginity from her. By adumbrating her potential loss of virginity with traditional symbolic imagery, Britomart becomes perceived as a woman warrior fighting to retain her image as Chastity. Overall, it becomes evident that her vow fuels her image as a knight because her sexual energy is harnessed to further promote her devotion to remaining a virgin-creating another medium for her two combating personas to converge and collide.

The duality that encompasses Edmund Spenser's The Faerie Queene arouses a tension that exists within the characters, the setting, and even the story itself. The main female protagonist, Britomart, epitomizes the notion of division that Spenser revolves his poem around, allowing this tension to take the shape of a character that manipulates the story itself. Her ambivalent identity regarding her gender and sexuality (revolving around her chastity) conflict with each other in extreme fashions, which do not only create extreme dichotomies, but also weave together to blend into a beautiful, warrior-like persona. When she encounters Malecasta, Britomart's character reveals itself as she battles her male and female traits, her aggressiveness and her delicateness, as well as her purity and impurity. As she leaves the House of Ioue on her noble steed with the Redcrosse Knight, "her bright armes about her body dight:/ For nothing would she lenger there be stayd,/ Where so loose life, and so ungentle trade,/ Was usd of knights and ladies seeming gent" (FQ III.i.67). She wipes the blood of Malecasta's massacred knights onto her armor nonchalantly, disapproves of the lack of gentleness and hospitality that she received as she sought shelter at the House, and continues forth on her journey as Spenser's image of duality. She voyages throughout the rest of the poetical work as the knight and lady, virgin and penetrator, and prey and hunter, carrying with her the ambivalence of her true 
identity that fuels her existence, since all representations of her coalesce to create one of the gentlest yet most ferocious women in Renaissance literature.

\section{WORKS CITED}

Anderson, Judith H. Words That Matter: Linguistic Perception in Renaissance English. Stanford, CA: Stanford UP, 1996. Print.

Borris, Kenneth. Same-sex Desire in the English Renaissance: A Sourcebook of Texts, 14701650. New York: Routledge, 2004. Print.

Brown, Meg Lota, and Kari Boyd. McBride. Women's Roles in the Renaissance. Westport, CT: Greenwood, 2005. Print.

DiGangi, Mario. "Fulfilling Venus: Substitutive Logic and the Tribade's Agency." Sexual Types: Embodiment, Agency, and Dramatic Character from Shakespeare to Shirley. Philadelphia: University of Pennsylvania, 2011. Print.

Fisher, Will. Materializing Gender in Early Modern English Literature and Culture. Cambridge: Cambridge UP, 2006. Print.

"gride, v." "hart, n." Oxford English Dictionary Additions Series. 1997. OED Online. Oxford University Press. 22 June 2013 <http://dictionary.oed.com/>.

Hagstrum, Jean H. Sex and Sensibility: Ideal and Erotic Love from Milton to Mozart. Chicago: University of Chicago, 1980. Print.

Lewis, C. S. English Literature in the Sixteenth Century, excluding Drama. Oxford: Clarendon, 1954. Print.

McCoy, Richard C. The Rites of Knighthood: The Literature and Politics of Elizabethan Chivalry. Berkeley: University of California, 1989. Print.

Mitchell, Marea, and Dianne Osland. Representing Women and Female Desire from Arcadia to Jane Eyre. Houndmills, Basingstoke, Hampshire: Palgrave Macmillan, 2005. Print.

Spenser, Edmund, Thomas P. Roche, and C. Patrick. O'Donnell. The Faerie Queene. Harmondsworth: Penguin, 1978. Print. 